Gudmund Hernes (f. 1941) er professor ved Handelshøyskolen BI og forsker ved Fafo, og var helseminister i perioden 1995-97.

Ingen oppgitte interessekonflikter.

Litteratur

1. Gjessing H. Pasientens eller helsepersonellets helsetjeneste? Tidsskr Nor Legeforen 2015; 135: 1091

2. Michael MQ. 2013; 10:119-22. http://www.dnms.no/index.php?setPublikasjon= true\&seks_id=156998 (22.6.2015).

\section{H. Gjessing svarer:}

Takk til Gudmund Hernes for at han minner leserne om en rekke stortingsmeldinger og andre plandokumenter som Legeforeningen er kjent med. Disse dokumentene omhandlet både helse- og omsorgstjenesten, helse- og sosialtjenesten og ved en anledning - $\mathrm{i}$ hans egen tid som helseminister - en melding om legetjenesten i kommunene. Sistnevnte var en viktig milepæl for utviklingen av fastlegeordningen.

St.meld. nr. 47 (2008-2009) om samhandlingsreformen tok prisverdig for seg samhandling i hele behandlingsforløpet i og mellom tjenestenivåene i den samlede helse- og omsorgstjenesten.

Den sittende regjering har levert en stortingsmelding som den selv omtaler som den første av sitt slag, fordi den beskriver primærhelsetjenesten som en helhetlig helsetjeneste. Meldingen har som ambisjon å se de ulike deltjenestene i kommunehelsetjenesten i sammenheng og å bygge ned «siloene» mellom dem. Legeforeningen støtter intensjonen med meldingen, men har også enkelte kritiske innvendinger.

\section{Hege Gjessing}

hege.gjessing@legeforeningen.no

Hege Gjessing (f. 1972) er President i Den norske legeforening Ingen oppgitte interessekonflikter.

\section{Re: Cannabis som medisin}

Jeg har et par kommentarer og noen spørsmål til Bramness sin kronikk om cannabis i Tidsskriftet nr. 3/2015 (1). Han skriver: «En del cannabisaktivister hevder at stoffets medisinske anvendelighet taler for legalisering. Medisinsk marihuana er i USA blitt brukt som brekkstang for dette, men til tross for det som er beskrevet over, hviler mye av den medisinske bruken på et for svakt empirisk grunnlag». Men har forfatteren undersøkt hvorvidt straffereaksjoner har vært en suksess? Finnes det et eneste gyldig grunnlag for bruk av tvangsmakt rent samfunnsmedisinsk, og individuelt?

Bramness skriver også: «Men jeg tror ikke leger har en rolle i denne viktige forebyggende delen av en slik fremtid.» Jeg mener det er selvfølgelig at leger har en viktig rolle. Det er helsevesenets oppgave å bedrive opplysning og forebyggende arbeid, ikke politi og rettsvesen.

\section{Morten Alme \\ morten.alme@gmail.com}

Morten Alme (f. 1972) er selvstendig næringsdrivende/skribent. Ingen oppgitte interessekonflikter.

Litteratur

1. Bramness JG. Cannabis som medisin. Tidsskr Nor Legeforen 2015; 135: 252-3.

\section{Re: E-sigaretter - til skade eller nytte?}

Det er trist når vitenskap og personlige meninger blandes sammen, slik som i Sanner og Grimsruds kronikk om e-sigaretter og i deres svar i diskusjonen i etterkant (1). Jeg har aldri røykt og er nokså nøytral i forhold til røyking. Imidlertid er det et faktum at mange røykere har hatt problemer med å slutte, og for disse mener jeg det ville være et stort fremskritt å gå over til e-sigaretter.

Hvorvidt professor Odd G. Nilsen en gang har fått støtte fra tobakksindustrien synes jeg er helt irrelevant i diskusjonen om e-sigaretter. Dette angrepet er vel et eksempel på å ta mannen og ikke ballen når en ikke har faglige argumenter.

Jeg vil holde fast på at vår nikotininhalasjonsstudie på rotte er den beste, og kanskje den eneste, adekvate studie vedrørende e-sigaretters toksisitet. Det reises spørsmål om dosering og lengde av studien vår. Dette tyder på forfatternes manglende biologiske forståelse. To år hos rotte med en forventet levealder på tre år vil tilsvare minimum 40 års eksponering hos menneske. Hva gjelder dose nikotin, ga altså vår eksponering den doble nikotinkonsentrasjon i blod av det en finner hos storrøykere (2). Dermed skulle det ikke være noen tvil om at dose og eksponeringstid var tilstrekkelig i vår studie.

Min konklusjon er altså at det er bra å være i mot tobakksrøyking. Ut fra generelle betraktninger er det også argumenter for å advare ikke-røykere mot e-sigaretter. Imidlertid ville det være en stor helsegevinst dersom tobakksrøykere gikk over til e-sigaretter. Dersom dette hadde vært fulgt opp for lenge siden, mener jeg mange ville ha unngått alvorlige sykdommer.

\section{Helge Waldum}

helge.waldum@ntnu.no

Helge L. Waldum (f. 1946) er professor ved St. Olavs Hospital/NTNU. Ingen oppgitte interessekonflikter.

\section{Litteratur}

1. Sanner T, Grimsrud TK. E-sigaretter - til skade eller nytte? Tidsskr Nor Legeforen 2015; 135: 959-61.

2. Waldum HL, Nilsen $O G$, Nilsen $T$ et al. Long-term effects of inhaled nicotine Life Sci 1996; 58: 1339-46.

\section{T. Sanner \& T.K. Grimsrud svarer:}

«Nilsen jobbet for Philip Morris i en årrekke etter at Ekspertgruppen ble nedlagt i 1992 og hentet inn store beløp fra tobakksgiganten» (1). Artikkelen til Waldum, Nilsen mfl (2). ble sendt inn for publisering i februar 1996. Således har studien etter all sannsynlighet pågått mens Nilsen jobbet med betaling fra Philip Morris. Studiene er ikke utført etter reglene for GLP (Good Laboratory Practice) (3).

På grunn av lav følsomhet ved dyreforsøk, brukes vanligvis mange ganger høyere konsentrasjon i dyreforsøk enn det mennesker er utsatt for. I dette forsøket var konsentrasjonen av nikotin av samme størrelsesorden som hva røykere utsettes for. Vår vurdering er derfor at modellen ikke er godt egnet til å studere konsekvenser av nikotineksponering. Overlevelsen var meget lav. Både etter 1,5 år og ved forsøkets slutt var overlevelsen høyere i den eksponerte gruppen enn i kontrollgruppen ( $21 \%$ av kontrollene mot $32 \%$ av de eksponerte rottene var i live da forsøket ble avsluttet etter to år) (2). Det er angitt at $24 \%$ av rottene i kontrollgruppen mot $36 \%$ av de eksponerte dyrene utviklet svulster, men det er ingen opplysninger om tidspunkt for svulstutvikling. Det er således ikke mulig å trekke noen konklusjon fra forsøket.

\section{Tore Sanner \\ tore.sanner@kjemi.uio.no \\ Tom K. Grimsrud}

Tore Sanner (f. 1935) er professor emeritus. Han var tidligere forskningssjef ved Institutt for kreftforskning, Radiumhospitalet, og professor II ved Kjemisk institutt, Universitetet i Oslo.

Ingen oppgitte interessekonflikter.

Tom K. Grimsrud (f. 1955) er dr.med., spesialist i arbeidsmedisin og overlege/forsker ved Kreftregisteret.

Ingen oppgitte interessekonflikter. 
Litteratur

1. Norske professorer fikk tobakks-penger. Verdens Gang 8.2.2002. www.vg.no/ nyheter/innenriks/norske-professorer-fikk.../a/1338398/ (6.7.2015).

2. Waldum HL, Nilsen OG, Nilsen T et al. Long-term effects of inhaled nicotine. Life Sci 1996; 58: 1339-46.

3. http://www.oecd.org/chemicalsafety/testing/goodlaboratorypracticeglp.htm (6.7.2015)

\section{Re: Hvordan leger ikke ønsker å dø}

Som pårørende vil jeg gjerne komme med noen kommentarer til artikkelen til Liv-Ellen Vangsnes om overbehandling i livets sluttfase (1). Min mor døde for noen år siden, 94 år gammel. Hun bodde på et eldresenter de siste årene, hvor hun hadde sin egen leilighet.

Dagen før hun døde spiste vi middag og kveldsmat sammen. Min mor døde på morgenen, etter at hun hadde fått hjelp til morgenstellet og frokost. Hun sovnet stille og rolig inn mens hun lå i sengen, da hun ønsket å hvile etter frokosten. Da personalet oppdaget at hun var død, opprettet de raskt kontakt med akutten. Ambulansen ble tilkalt, og ambulansepersonalet startet med intensiv gjenopplivning, med utstyr og slanger som dette medførte. Hun våknet ikke til liv igjen.

Min mor var, tross sin høye alder, «klar og tydelig i hodet» helt fram til det siste. Vi snakket gjerne om døden. Hun sa at hun var sliten i kroppen og hadde levd et langt og godt liv, og at hun nå ønsket å dø. Hun hadde sin kristne tro og snakket om sin egen avslutning på livet som en naturlig del av det å leve. Jeg som sønn ble ikke orientert av personalet på eldresenteret om at det ville bli igangsatt gjenopplivning. Noe jeg ville ha sagt nei til med henvisning til mine samtaler med min mor, og med respekt for hennes meninger.

I ettertid ser jeg det nesten som et overgrep på min mor at hun ikke fikk lov til å avslutte livet på en stille og rolig måte, og at andre mennesker besluttet at hun skulle forsøkes gjenopplivet mot hennes klare vilje. Jeg ser også at jeg (og mor) burde ha orientert personalet om hvordan hun ønsket å dø, men jeg trodde ikke at dette ville skje når hun var så gammel. Her mener jeg det burde være en rutine for at personalet har en samtale med den aktuelle og evt. pårørende om hvordan den enkelte ønsker å avslutte livet.

Jeg vil også legge til at da jeg kom til hennes leilighet etter hennes død, ble jeg av personalet nektet å komme inn i leiligheten. Begrunnelsen var at de ønsket å fjerne slanger og stelle henne før jeg fikk lov til å komme inn. Denne hendelen var faktisk det jeg opplevde som det mest ubehagelige og respektløse ved min mors død. Det virket på meg at personalet var mer redd for døden enn hva min mor og jeg var, både da hun levde og da hun var død.

\section{Erling Østberg}

e.ostberg@yahoo.no

Erling Østberg (f. 1954)

Ingen oppgitte interessekonflikter.

\section{Litteratur}

1. Vangsnes L-E. Hvordan leger ikke ønsker å dø. Tidsskr Nor Legeforen 2015; 135: 919.

\section{Re: $0 \mathrm{~m}$ å møte seg selv og andre i døren}

Takk for en ærlig og etterlengtet reaksjon på en særdeles ukritisk artikkel publisert i Tidsskriftet januar 2015. Frøisland tar i sine refleksjoner opp hvordan vi som leger kan ha godt av å møte oss selv i døren (1). Det er lett å kjenne seg igjen i hans beskrivelser. Vi jobber hver dag omringet av lidelse, tap og sorg. Vi møter mennesker i krise med behov for både empati og forståelse for den situasjonen de befinner seg i. Hvordan kan vi som leger være i stand til dette hvis vi ikke tåler svakheten i oss selv? Hvordan kan vi ha en genuin empati og forståelse for andres tilkortkommenhet, når vi ikke kan vedkjenne oss at vi alle kommer til kort?

Tid til selvrefleksjon er viktig. Vi har gått inn i et yrke hvor vi har mange «møter» i løpet av en uke; med pasienter, med pårørende og med kollegaer. Som Frøisland beskriver, er vi mennesker som har jobbet hardt for å være der vi er i dag. Og vi har fått bekreftelser på egenskapene vi innehar som har gjort det mulig å oppnå de målene vi har satt oss. Vi har fått bekreftelser på våre prestasjoner. Vi er flinke! Og det er bra! Det å være flinke og ressurssterke, som enkeltpersoner og som gruppe, må ikke stå i kontrast til å stoppe opp, trekke pusten, senke tempoet eller prioritere annerledes. Vi må være rause med oss selv og med våre kollegaer - $\mathrm{i}$ hverdagen, når livet blir mye, når vi ikke bare er mestrende, når vi blir små og når vi trenger å bli sett!

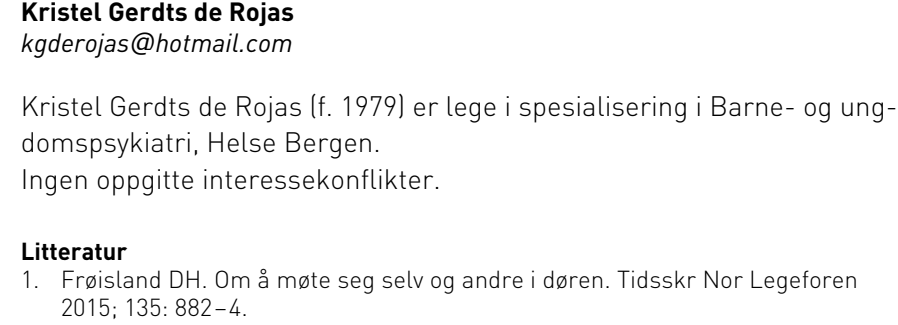

\section{RETTELSER}

\section{En entusiastisk altmuligmann}

Marit Tveito

Tidsskr Nor Legeforen 2015; 135: 846-8.

I intervjuet med Kjetil Søreide i Tidsskriftet nr. 9/2015 skal det i 1. Linje i 3. avsnitt på s. 846 stå: Han bor på Stokka i Stavanger... Og i det femte faktapunktet på s. 847 skal det stå: Professor ved Klinisk institutt 1 , Universitetet i Bergen, fra 2011

Vi beklager feilen, den er rettet på nett.

Legens venteværelse

Erlend Hem

Tidsskr Nor Legeforen 2015; 135: 1152-3

I Tidsskriftet nr. 12-13/2015 s. 1152 og 1153 sist i fotokrediteringene skal det stå: ( ) Kåre Kivijärvi/BONO 2015

Vi beklager feilen, den er rettet på nett. 